This item was submitted to Loughborough's Research Repository by the author.

Items in Figshare are protected by copyright, with all rights reserved, unless otherwise indicated.

\title{
Somewhere in between: blogging as an intermediate and accessible space
}

PLEASE CITE THE PUBLISHED VERSION

https://doi.org/10.1386/jwcp.11.1.67_1

PUBLISHER

(c) Intellect

VERSION

AM (Accepted Manuscript)

PUBLISHER STATEMENT

This work is made available according to the conditions of the Creative Commons Attribution-NonCommercialNoDerivatives 4.0 International (CC BY-NC-ND 4.0) licence. Full details of this licence are available at: https://creativecommons.org/licenses/by-nc-nd/4.0/

\section{LICENCE}

CC BY-NC-ND 4.0

\section{REPOSITORY RECORD}

Morris, Mhairi. 2019. "Somewhere in Between: Blogging as an Intermediate and Accessible Space". figshare. https://hdl.handle.net/2134/27463. 
Title: Somewhere in between: blogging as an intermediate and accessible space

Author: Dr Mhairi A Morris

Address: Loughborough University, Towers Way, Loughborough, LE11 3TU

Email: M.A.Morris@lboro.ac.uk

Tel: $+44(0) 1509226345$

\begin{abstract}
The learning process involves contextualising new knowledge with prior experiences and beliefs. In the scientific discipline, the focus of learning is geared towards learning how to do science, but there are significant barriers to learning, including jargonised terminology and excessive use of acronyms. Scientific discoveries are made by experimentation, but science as a discipline progresses through a series of ongoing conversations. Blogging provides a platform that widens access to these conversations by communicating science in a style of writing that sits somewhere in between the formal and informal. Regenring scientific writing as a blog can enhance student learning by breaking down the barriers to learning posed by 'intellectually inaccessible' information. Here, I describe an experimental approach to teaching cancer biology by regenring a classic review article in the field as a series of blog pieces, using everyday metaphors and analogies to describe the characteristics and behaviour of cancer cells. Other aspects of discipline, identity, 'voice' and communities of practice are also considered. Until such time as blogging is recognised as a valid academic output, however, it will remain firmly somewhere in between.
\end{abstract}

\title{
Introduction
}

At the heart of every learning experience is the way in which a student processes their own experiences, critically, in the context of newly acquired information. In the early 1990s, Mayer outlined a paradigm shift in education from a focus on the curriculum and the importance of acquiring knowledge and facts, to one in which educators are focused on developing learners' metacognitive skills and learning strategies: in other words, enabling learners to understand their own learning processes (Mayer, 1992). It follows, then, that successful learners are able to make meaning of the information they acquire in the context of their own prior beliefs and experiences. Moreover, successful learners can make connections between items, even those seemingly unrelated, and develop their own explanations by elaborating on their existing knowledge (Reynolds et al., 2012).

Learning in science is not merely the memorisation of long strings of facts, but instead is concerned with how to be a scientist, which is achieved by learning how to do science. This involves the development of the skills, attitudes and knowledge of how scientists do science (Barab and Hay, 2001). However, the literature backing up the scientific knowledge base (strings of facts) is fraught with difficulties for many undergraduate students in scientific disciplines, and this is further compounded by the complex methods used by scientists to make their discoveries. Confusion, overwhelm, and ultimately, demotivation are common emotions amongst undergraduate science students, and are symptomatic of the use in the field of highly specialised and jargonised terminology, a penchant for acronyms, and the sheer velocity at which new knowledge is discovered (according to Stuart Firestein in his highly acclaimed book, 'Ignorance: How It Drives Science' (Firestein, 2012), there is an approximate doubling in the number of scientific articles every 10-12 years with the most 
recent doubling bringing 1,000,000 new publications!). Even textbooks, which are written in a (somewhat) more accessible and engaging prose, can be a 'dry read'. The result is an impenetrable 'disciplinary discourse' that has the potential to alienate and exclude.

Whilst scientific discovery occurs in the laboratory through a series of experiments, science itself, as a subject discipline, moves forward based on a series of ongoing conversations (Batts, Anthis and Smith, 2008). In 'How Writers Journey to Comfort and Fluency: A Psychological Adventure', Robert Boice uses metaphor to describe the process of writing as a matter of 'joining an ongoing conversation' where listening precedes writing (Boice, 1994). Traditionally, these conversations will have happened almost exclusively in the academic realm between academic intellectuals conducting research at higher education institutions across the globe. These conversations may be held physically, at conferences, networks or meetings, or in written form, with the premise of the scientific journal being 'a special kind of story, of an event created so that it might be told,' (Ball et al., 1988). However, the Internet revolution has played an interesting role in democratising access to knowledge, and the rise of the 'blogosphere' has allowed the indiscriminate giving of 'voice' to all - or at the very least, to all who wish to 'speak'. In this way, writing about science, formally or informally, can enable participation in the 'ongoing conversation' that moves science forwards. Indeed, used effectively, blogs have the potential to inspire the next generation of scientists since they can 'demythologize science', sharing the power and agency of the academic realm with the general public (Batts, Anthis and Smith, 2008; Wilkins, 2008). Thus, the elitism that traditionally surrounds knowledge building, access to information and 'having a voice' may be perceived to be in decline. That which was once the preserve of academic intellectuals is now open to ordinary folks (or as Gramsci may have called them, 'organic intellectuals'; (Storey and Storey, 2006; Daniels and Feagin, 2011).

'Blogademia' (a term coined by Saper in 2006 to categorise academic blogs as a genre of blogs in itself) presents a unique 'educational bridge' between the seemingly 'intellectually inaccessible' academese (which often also sits behind expensive pay-walls) and the general public, by distilling important experimental findings into an accessible and interactive platform for taking part in the ongoing conversations that move science forwards (Batts, Anthis and Smith, 2008). Blogging has opened up this conversation to the 'organic intellectuals', as evidenced by the growth of new science blogs in recent years, written by both academics and interested members of the general public alike.

The term 'regenring' refers to the re-imagining of a piece of academic work (usually writing) in a different, generally more accessible format using a non-traditional genre (English, 2011). Blogging is one such method of regenring, and has been successfully used in academe in a variety of different ways: as a means of communicating research findings to the public; as a personal account of one's experience in academe; and of course, as an educational tool. Furthermore, there is a growing awareness of blogging as a writing or communicative genre in academe (Heap and Minocha, 2012) and as a new form of scholarship (Halavais, 2006). It affords a new genre of accessible academic output, forming disciplines within spaces of 'digital genre scholarship' (Weaver, 2014), conferring upon academe the role of 'public intellectual' by opening up the ongoing conversations that drive science forwards (Kirkup, 2010). Thus, regenring through academic blogging has the potential to reshape social practices within an academic discipline.

Ivanič (1998) poses the idea that all writing is a presentation of the self (Ivanič, 1998). Traditional academic writing creates an identity as an academic, however students and 
academics alike cannot always necessarily identify with academic writing (Kirkup, 2010). Thus, problems arise when asked to produce a piece of academic writing. I need only point you to the long list of self-help books available on the subject to convince you that this is the case. Blogging may provide students with an alternative place to create academic identity that is more accessible and less troublesome than traditional ones, and a place to find their 'voice' in the ongoing conversation. However, it is less enthusiastically embraced as offering an alternative for academics because of the difficulties surrounding the perception of blogs not being an academic product (Lovink, 2008).

Etienne Wenger defines a community of practice as 'a group of people who share a concern or a passion for something they do and learn how to do it better as they interact regularly,' (Wenger and Wenger-Trayner, 2015). Blogging is therefore an establishing of digital communities of practice where scholarship and knowledge is shared (Weaver, 2014). Linking this concept with the idea of joining a conversation and the notion of academic identity, regular academic blogging enables participation in a conversation beyond the academic self.

However, as accessible as blogs may be, and with the potential to produce significant impact through engaging society, blogging is not currently accepted as a valid academic output, primarily because anyone can publish a blog piece without having to submit to the rigorous peer review processes that are endemic in academe. Blogs, in effect, occupy an intermediate space, somewhere in between more established writing forms, blurring the boundaries between the formal and the informal (Heap and Minocha, 2012).

Regardless, exploiting blogging as an educational tool in our teaching practices can help to make the ongoing conversation more accessible to learners. Here, I present a case study where blogging is used as a regenred 'disciplinary discourse' in cancer biology to break down the barriers to learning in a cohort of students studying the biochemistry of cancer.

\section{Edublogging in practice: a case study}

The term 'edublogging' is used to describe the use of blogging as an educational tool. As a true scientist, right through to my core, I cannot help but experiment with things, including my teaching practices. Here I discuss my experiment with edublogging as a means of providing an accessible introduction to the topic for my level 5 cancer biology lectures to a vastly diverse cohort of circa 120 students enrolled on the Biomedical Science undergraduate degree at De Montfort University, Leicester. The cohort comprised a majority of native English speakers, a small number of international students for whom English is their second language, a high proportion of black and minority ethnic students, and a wide range of abilities and entry grades. A high proportion entered university with a BTEC qualification (or equivalent).

\section{Contextualising the problem}

The field of cancer biology is a highly specialised subject area that is rife with jargon, acronyms, and requires a strong foundation of background knowledge about the processes underlying cell growth, division, survival and movement.

In their seminal paper in 2000, Hanahan and Weinberg described six fundamental hallmarks of cancer in a review of the literature at that time (Hanahan and Weinberg, 2000). At only 13 pages in length, it is a relatively short review, and would take the average academic in the field less than an hour to fully digest. I include it as an essential recommended text for my cancer biology lectures, and expect students to familiarise themselves with the six 
characteristics common to all cancers described within. However, feedback from previous years indicate that the introduction of new terminology, the heavy use of jargon and the hefty prose render the paper considerably 'intellectually inaccessible' to the average student. The result: students would not read it! This was a problem, and one I needed to find a solution for.

\section{Rationale for curriculum redesign}

Knowing that the use of imagery, stories and metaphors are powerful learning tools (Abawi, 2013), and armed with the (perhaps clichéd) mantra that 'a picture tells a thousand words' I began by replacing much of the text on my lecture notes with images (for example, compare Figure 1 with Figure 2). Whilst this worked during the lecture, it did not help students when the time came to revise the content for the end of year examinations: their success was heavily reliant on their ability to take effective notes during the lectures. If they did not understand the context, or were being introduced to lots of new terminology, this made their task even more challenging.

Therefore, in an experimental effort to increase student understanding of this complex new topic (the biochemistry of cancer) I created a blog where I laid out the key information to support a series of lectures, written in simple, easy-to-understand prose. 'Perspectives on Cancer' uses everyday analogies and metaphors to draw comparisons between the behaviours and characteristics of cancer cells with concepts students would be familiar with, for example likening the growth of cancer cells with the process of making pizza (https://www.perspectivesoncancer.com/hallmarks-of-cancer/; see examples two, three and four below). By introducing the students to the topic area in advance of the lecture, including any new terminology or jargon they would need to become familiar with, I hoped that students would be more readily able to 'keep up' during the lectures.

The students on the course were emailed instructions with a link to the relevant blog piece as essential pre-reading ahead of the lecture. Then, at the beginning of the lecture, I checked in with them to ascertain whether or not they had read the blog in advance (some had not, but most had). I would then deliver the lecture, referring back to the relevant metaphors and analogies used in the blog piece as appropriate.

\section{Results from a new approach}

In the five examples laid out below, the new knowledge or fact I wished to convey is presented in the subheading (in bold and italics), and is followed by an excerpt from the scientific journal (Hanahan and Weinberg, 2000). I then include an excerpt from the blog, and where relevant, I also include a screenshot of the corresponding lecture slide. Finally, I include a short analysis comparing the two different genres of prose.

\section{Example \#1 - Cancer cells require nutrients for growth}

An excerpt from 'The Hallmarks of Cancer':

'Normal cells require mitogenic growth signals (GS) before they can move from a quiescent state into an active proliferative state [...] Dependence on growth signaling is apparent when propagating normal cells in culture, which typically proliferate only when supplied with appropriate diffusible mitogenic factors and a proper substratum for their integrins. Such behavior contrasts strongly with that of tumor cells, which invariably show a greatly reduced dependence on exogenous growth stimulation.'

An excerpt from the blog: 
'[...] cancer is essentially a mass of cells that refuse to die. This means they keep on growing and dividing. In order to facilitate this prolific growth, they need nutrients in the form of growth factors, but their rapid growth would mean in an ordinary setting they would soon exhaust the body's natural stores.'

\section{Analysis:}

Consider the jargon-laden excerpt from the journal above: in this short paragraph alone, the student meets at least eight specialised words (mitogenic, quiescent, proliferative, propagating, diffusible, substratum, integrins, exogenous), many of which may be entirely new to them. To understand the context, it is possible that a student may need to pause to look up each of these eight terms, then return to the text and re-read the section (and perhaps re-read it again) to make meaning of this new-found knowledge in the context of their already existing knowledge base. By regenring this piece into a more accessible, conversational prose, it unpicks the disciplinary discourse alluded to by Wenger whereby the cohort of students (the community of practice; Wenger, 1998) are more readily able to access the 'ongoing conversation' that drives forward the scientific discipline (Batts, Anthis and Smith, 2008).

\section{Example \#2 - Cancer cells make more growth factors}

From 'The Hallmarks of Cancer':

'While most soluble mitogenic growth factors (GFs) are made by one cell type in order to stimulate proliferation of another - the process of heterotypic signalling - many cancer cells acquire the ability to synthesize GFs to which they are responsive, creating a positive feedback signaling loop often termed autocrine stimulation. Clearly, the manufacture of a GF by a cancer cell obviates dependence on GFs from other cells within the tissue. The production of PDGF (platelet-derived growth factor) and TGF $\alpha$ (tumor growth factor $\alpha$ ) by glioblastomas and sarcomas, respectively, are two illustrative examples.'

\section{From the blog:}

'Therefore, cancer cells can acquire mutations that cause them to overexpress genes that encode for growth factors, thereby providing themselves with their own supply of 'food'. To use an analogy, think of it as cooking a pizza with ingredients from the cupboard. Everything you need is all 'in house', you just need to get a bit creative and put the right things together in the right order, then stick it in the oven to cook' 


\section{Self-sufficiency in growth signals}

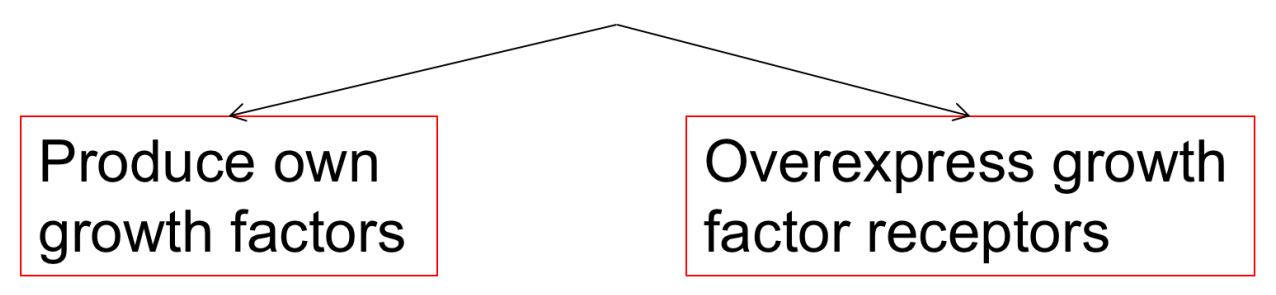

\section{Define:}

- Autocrine

- Paracrine

- Intracrine

- Endocrine

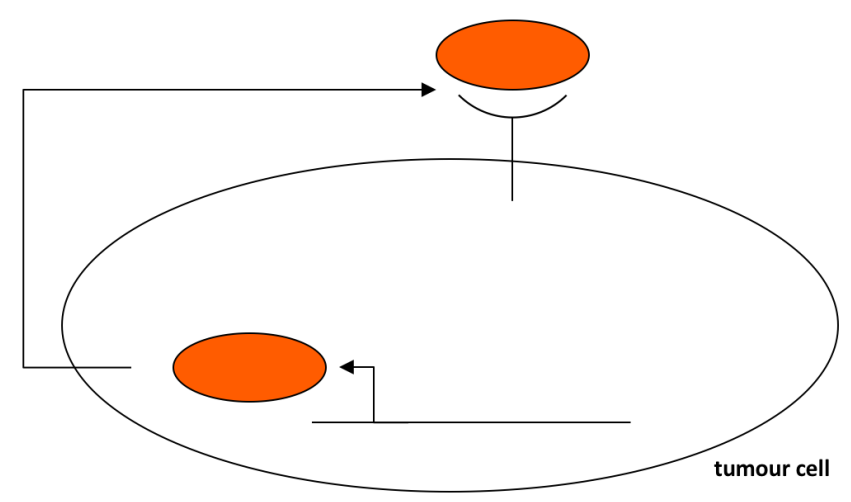

Figure 1: self-sufficiency in growth signals is one of the hallmarks of cancer

By using a simple diagram, the concept of cancer cells making their own growth factors and overexpressing the receptors that bind to these growth factors is clearly conveyed.

\section{Analysis:}

During the lecture, drawing on the analogy of making pizza from ingredients in the cupboard helps the students to remember that the cancer cell is using growth factors from its own 'larder'. This is infinitely more memorable than 'cancer cells acquire the ability to synthesize GFs to which they are responsive, creating a positive feedback signalling loop often termed autocrine stimulation'. Furthermore, when students meet the phrase 'autocrine stimulation' again, they will more likely be able to recall the meaning of this phrase quickly by reference to their bank of contextualised metaphors. By linking metaphor to understanding, it creates cognitive connections by forming a cognitive 'place' where new and old understandings converge, thereby helping embed student learning (Abawi, 2013).

\section{Example \#3 - Cancer cells express more growth factor receptors}

From 'The Hallmarks of Cancer':

'The cell surface receptors that transduce growth-stimulatory signals into the cell interior are themselves targets of deregulation during tumor pathogenesis. GF receptors, often carrying tyrosine kinase activities in their cytoplasmic domains, are overexpressed in many cancers. Receptor overexpression may enable the cancer cell to become hyperresponsive to ambient levels of GF that normally would not trigger proliferation.'

From the blog:

'In addition to this, tumour cells can overexpress the number of growth factor receptors on their cell surface, enabling them to be more responsive to this increase in self-service of 
growth factors. Continuing with the pizza analogy, imagine growing an additional mouth, or three! How much more pizza can you consume now?! (Although, perhaps you'd also need to grow additional stomachs too....?)'

\section{Analysis:}

Having a little fun with the metaphors, as in the above example where I call upon the students to imagine how much more pizza they could eat if they had more than one mouth, is another 'trick' to help the brain remember information. The human brain is exceptionally well-versed in noticing differences (big and small), idiosyncrasies and seemingly random (but interesting) facts (Dunleavy, 2015).

Example \#4 - Cancer cells stimulate neighbouring cells to produce more growth factors From 'The Hallmarks of Cancer':

'Heterotypic signaling between the diverse cell types within a tumor may ultimately prove to be as important in explaining tumor cell proliferation as the cancer cell-autonomous mechanisms enumerated above. For example, we suspect that many of the growth signals driving the proliferation of carcinoma cells originate from the stromal cell components of the tumor mass [...] successful tumor cells are those that have acquired the ability to co-opt their normal neighbors by inducing them to release abundant fluxes of growth-stimulating signals.'

From the blog:

'Cancer cells can also stimulate neighbouring cells to produce more growth factors - a bit like ordering in a pizza for delivery when you run out of ingredients for making your own.'

\section{Sustaining proliferative signalling (mitogenic signals)}

1. Producing growth factor ligands themselves (autocrine)

2. Stimulate normal cells in tumoursupporting stroma to produce growth factors (paracrine)

3. Upregulate cell surface expression of growth factor receptors

4. Constitutive activation of components of signalling pathways operating downstream of these receptors
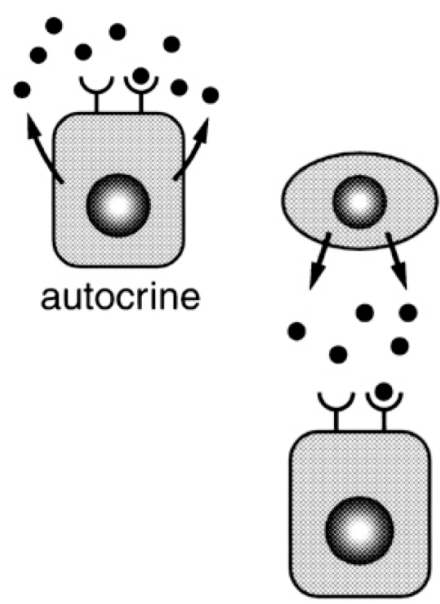

paracrine

5. Disruption of normal negative-feedback loops

Figure 2: summary slide of the ways in which cancer cells sustain growth signalling 
Whilst this slide is a little more text-heavy than I would ordinarily allow, sometimes words prevail, especially when summarising key points. It also facilitates the process of learning and embedding discipline-specific terminology, which has already been unpacked with the pizza metaphor.

Analysis:

By continuing with the same metaphor, extending the context, the students are equipped with a memory-aide to recall the ways in which cancer cells can sustain their own growth. Interestingly, Hanahan and Weinberg (2000) also use similar terminology in describing a tumour cell's ability to 'co-opt their normal neighbors', yet this simple phrase is shrouded within a hazy fog of complex, jargonised terminology. At this stage, I point out to the students that reading a scientific paper is simply a matter of 'uncomplicating' it: I tell them to break it down into smaller chunks, reword it in a way they understand, then check if it fits within the context of what they have already learned and understood. In effect, I am 'demythologizing science', as Wilkins said (Wilkins, 2008).

\section{Example \#5 - Cancer cells can signal, even without growth factors bound to their receptors}

From 'The Hallmarks of Cancer':

'The most complex mechanisms of acquired GS autonomy derive from alterations in components of the downstream cytoplasmic circuitry that receives and processes the signals emitted by ligand-activated GF receptors and integrins. The SOS-Ras-Raf-MAPK cascade plays a central role here. In about $25 \%$ of human tumors, Ras proteins are present in structurally altered forms that enable them to release a flux of mitogenic signals into cells, without ongoing stimulation by their normal upstream regulators.'

From the blog:

'Tumour cells can bypass the need for growth factors altogether by constitutively activating signalling pathways downstream of the growth factor receptors. Put simply, this means causing the signalling pathways to always be firing a signal inside the cell, regardless of whether or not a growth factor has bound to the receptor outside the cell. Remember the children's story about the magic porridge pot that kept on making more and more porridge itself until the little girl told it to stop? Well, in some ways, constitutive activation of signalling pathways is a bit like this. In an ordinary healthy cell, a negative feedback loop would be in place to dampen the pro-growth signals and maintain homeostasis. This often goes awry in cancer - a bit like silencing the little girl in the story....'

\section{Analysis:}

To complete this section of the blog on that particular hallmark of cancer, I draw similarities between the cancer cell continuously firing signals and the fabled children's story of the magic porridge pot that continued to make porridge until the little girl told it to stop. Although my example lacks the specific mention of the Ras signalling cascade, and is actually a lengthier paragraph, it is (in my opinion and reassuringly backed up by student feedback) easier to understand.

\section{Discussion}

The value of edublogging in the learning environment

Re-defining my approach to teaching a complex topic took a lot of time and effort but the results were worth it. Data collated from student feedback indicated that regenring scientific 
literature in the form of a blog was helpful to enhancing their learning. Some free-form comments from students included:

'Absolutely loved the blogs!'

' $[\ldots]$ the blog is amazing. Very helpful! $<3$ '

'Different techniques are used which makes lectures and tutorials more creative.'

'Love your blogs. Learnt a lot from these'

Importantly in the context of this discussion, none of the free-form comments were negative about the use of blogging on this course, although that in itself, of course, does not mean the students were unanimously in favour of this teaching technique.

Blogs used as a classroom tool can promote and enhance learning at universities, and there are many successes to cite, including high satisfaction with student interest, learning, and commitment when blogs form part of the classroom learning environment (Downes, 2004). This 'community of practice', as Wenger describes it, provides a space in which students can learn the modes of thinking and enquiry specific to their discipline (Wenger, 1998). It is worth noting that forcing students to create their own blogs ('flogging') is rarely effective, but where used as an integrated component of the course, for example where student-created blogs are used as a form of assessment, they can prove beneficial (Karrer, 2007).

As noted earlier, successful learners develop their own explanations by elaborating on their existing knowledge (Reynolds et al., 2012). One could argue that with this regenring exercise I have done the 'elaboration' aspect of their learning for them. This raises the question of whether it would be more valuable for the students to write their own blogs, regenring scientific articles to help cement their knowledge and understanding. Indeed, in a study amongst music students who kept a blog to accompany their final year research project, one student noted, '[k]nowing that my blog is in the public domain, it also forces me to put my notes down in an organised form and in a language readers can understand [...] blogging acts as a framework for discipline,' (emphasis added). Peer-learning was also reported as a benefit (Chong, 2010).

Extending the notion of being part of an ongoing conversation, edublogging can be a useful tool to facilitate discussions in class (Downes, 2004), providing students with a vehicle through which to develop their own 'critical intellectual voice' (Oravec, 2003). Students appreciate being able to express their opinions, and blogs provide them with a place to 'think aloud' (Nackerud and Scaletta, 2008). As the German sociology professor, Niklas Luhmann, once said, 'One cannot think without writing.' (Luhmann, 1992), and so blogging provides the community of practice, that supports the writing, that facilitates the thinking.

However, I'm reminded of the warning from Karrer against 'flogging' (forced blogging; Karrer, 2007), and any future plans I may have for students in writing their own regenred science blogs will be carefully thought out and mapped to very clear and specific learning outcomes.

\section{Conclusion}

Taking my own experiences of 'edublogging' together with evidence from the current body of literature on the subject, it is apparent that blogs have the capacity to widen access to the knowledge and ongoing conversations within a given field. Adding value by creating effective learning environments, blogs also provide a 'framework for discipline' which encourages bloggers to think about the way they present themselves online. Developing an 
identity as a 'blogger' gives rise to a 'voice' to participate in ongoing conversations in the subject area. Building a habit of blogging in a digital community of practice helps foster the 'writing to think' approach advocated by Luhmann.

As a mode of communicating research, blogs sit somewhere in between the traditional forms of academic writing and the 'hot-right-now' science stories that spread like wild-fire on the Internet, lapped up and regurgitated by mass media. As a means of engaging the public, blogs sit somewhere in between the 'intellectually inaccessible' prose behind expensive pay-walls and the dubious 'pseudo-science' websites that sit on the fringe. As a writing form, blogs blur the boundaries somewhere in between the formal and the informal. However, at present, blogs are not recognised as valid academic outputs in traditional scholarly practice, so until such time as they are, blogs will continue to sit somewhere in between.

\section{References}

Abawi, L. (2013) 'Metaphor: Powerful imagery bringing learning and teaching to life', Improving Schools. SAGE PublicationsSage UK: London, England, 16(2), pp. 130-147. doi: $10.1177 / 1365480213492409$.

Ball, M. S. et al. (1988) 'Shaping Written Knowledge', p. 355. doi: 10.1126/science.248.4957.877.

Barab, S. A. and Hay, K. E. (2001) 'Doing science at the elbows of experts: Issues related to the science apprenticeship camp', Journal of Research in Science Teaching. John Wiley \& Sons, Inc., 38(1), pp. 70-102. doi: 10.1002/1098-2736(200101)38:1<70::AIDTEA $5>3.0 . \mathrm{CO} ; 2-\mathrm{L}$.

Batts, S. A., Anthis, N. J. and Smith, T. C. (2008) 'Advancing Science through Conversations: Bridging the Gap between Blogs and the Academy', PLoS Biology. Public Library of Science, 6(9), p. e240. doi: 10.1371/journal.pbio.0060240.

Boice, R. (1994) How writers journey to comfort and fluency : a psychological adventure. Praeger. Available at:

https://books.google.co.uk/books/about/How_writers_journey_to_comfort_and_fluen.html?id $=$ nByFAAAAIAAJ (Accessed: 16 August 2017).

Chong, E. (2010) 'Using blogging to enhance the initiation of students into academic research', Computers \& Education, 55, pp. 798-807. doi: 10.1016/j.compedu.2010.03.012.

Daniels, J. and Feagin, J. R. (2011) The (Coming) Social Media Revolution in the Academy, Fast Capitalism, 8.2. Available at:

https://www.uta.edu/huma/agger/fastcapitalism/8_2/Daniels8_2.html (Accessed: 16 August 2017).

Downes, S. (2004) 'Educational Blogging'. Available at:

http://er.educause.edu/ /media/files/article-downloads/erm0450.pdf (Accessed: 16 August 2017).

Dunleavy, P. (2015) Becoming more creative in academic work-Advice for authoring a PhD or academic book. Available at: https://medium.com/advice-and-help-in-authoring-aphd-or-non-fiction/becoming-more-creative-in-academic-work-eaba76c5d075 (Accessed: 16 
August 2017).

English, F. (2011) Student writing and genre : reconfiguring academic knowledge. Continuum.

Firestein, S. (2012) Ignorance : how it drives science. Oxford University Press. Available at: https://global.oup.com/academic/product/ignorance-9780199828074?cc=gb\&lang=en\& (Accessed: 16 August 2017).

Halavais, A. (2006) 'Scholarly blogging: Moving toward the visible college', Uses of blogs. Available at:

https://scholar.google.com/scholar?hl=en\&as_sdt=0,5\&cluster $=7341448335327628768$ (Accessed: 16 August 2017).

Hanahan, D. and Weinberg, R. A. (2000) 'The Hallmarks of Cancer Review evolve progressively from normalcy via a series of pre', Cell, 100, pp. 57-70. Available at: http://www.cell.com/cell/pdf/S0092-8674(00)81683-9.pdf (Accessed: 16 August 2017).

Heap, T. and Minocha, S. (2012) 'An empirically grounded framework to guide blogging for digital scholarship'. doi: 10.3402/rlt.v20i0.19195.

Ivanič, R. (1998) Writing and Identity. Amsterdam: John Benjamins Publishing Company (Studies in Written Language and Literacy). doi: 10.1075/swll.5.

Karrer, T. (2007) Learning and Networking With Blogs. Available at: https://www.td.org/Publications/Newsletters/Learning-Circuits/Learning-CircuitsArchives/2007/10/Learning-and-Networking-with-Blogs (Accessed: 16 August 2017).

Kirkup, G. (2010) 'Academic blogging: academic practice and academic identity', London Review of Education, 8(1), pp. 75-84. doi: 10.1080/14748460903557803.

Lovink, G. (2008) Zero comments : blogging and critical Internet culture. Routledge.

Luhmann, N. (1992) Communicating with Slip Boxes: An Empirical Account. Available at: http://luhmann.surge.sh/communicating-with-slip-boxes (Accessed: 16 August 2017).

Mayer, R. E. (1992) 'Cognition and instruction: Their historic meeting within educational psychology.', Journal of Educational Psychology, 84(4), pp. 405-412. doi: 10.1037/00220663.84.4.405.

Nackerud, S. and Scaletta, K. (2008) 'Blogging in the academy', New Directions for Student Services. Wiley Subscription Services, Inc., A Wiley Company, 2008(124), pp. 71-87. doi: $10.1002 /$ ss.296.

Oravec, J. A. (2003) 'Blending by Blogging: weblogs in blended learning initiatives', Journal of Educational Media, 28, pp. 2-3. doi: 10.1080/1358165032000165671.

Reynolds, J. A. et al. (2012) 'Writing-to-learn in undergraduate science education: a community-based, conceptually driven approach.', CBE life sciences education. American Society for Cell Biology, 11(1), pp. 17-25. doi: 10.1187/cbe.11-08-0064. 
Storey, J. and Storey, J. (2006) Cultural theory and popular culture : a reader.

Pearson/Prentice Hall. Available at: https://books.google.co.uk/books?hl=en\&lr=\&id=9IByKJVHd8C\&oi $=$ fnd\&pg $=$ PA85\&dq $=$ gramsci + organic + intellectual\&ots $=8$ vgDI1AdW\&sig=GJD3iK4txiNQuR2KunRq4kEpUmM\#v=onepage\&q=gramsci organic intellectual\&f=false (Accessed: 16 August 2017).

Weaver, S. (2014) 'Blogging' a Genre of Social Practice: Reaching Beyond the Academic Self $\mid$ Write To Matter. Available at:

https://writingcritical.wordpress.com/2014/05/05/blogging-a-genre-of-social-practicereaching-beyond-the-academic-self/ (Accessed: 16 August 2017).

Wenger, E. (1998) Communities of practice : learning, meaning, and identity. Cambridge University Press. Available at:

https://books.google.co.uk/books?hl=en\&lr=\&id=heBZpgYUKdAC\&oi=fnd\&pg=PR11\&dq $=$ wenger $+1998+$ communities + of + practice\&ots $=$ kfkc3mey_1\&sig=AHc4FIXSgrZRxGILlBEi $\mathrm{kR} 3 \mathrm{olMg} \# \mathrm{v}=$ onepage $\& \mathrm{q}=$ wenger 1998 communities of practice $\& \mathrm{f}=$ false $($ Accessed: 16 August 2017).

Wenger, E. and Wenger-Trayner, B. (2015) 'Introduction to Communities of Practice. A Brief Overview of the Concept and its Uses', Online: http://wenger-trayner. com/introduction-to-. Available at: https://scholar.google.co.uk/scholar?hl=en\&as_sdt=0,5\&cluster $=15525001639758390192$ (Accessed: 16 August 2017).

Wilkins, J. (2008) 'The roles, reasons and restrictions of science blogs', Trends in Ecology \& Evolution, 23(8), pp. 411-413. doi: 10.1016/j.tree.2008.05.004.

\section{Author Bio:}

Mhairi is a Biochemistry Lecturer at Loughborough University and honorary Senior Lecturer at De Montfort University (DMU) in Leicester. She attained Senior Fellow of the Higher Education Academy and DMU Teacher Fellow status in 2016.

Her research looks into the mechanisms underlying tumour growth and spread, and she has a particular interest in the preventative role that physical activity and exercise may play in these processes.

Mhairi joined the WritingPAD East Midlands network because of her keen interest in the intersection between science and creativity and her passion for using novel approaches to help students develop their academic writing skills. 